\title{
Ilmu Falak dan Perannya dalam Beberapa Cabang Fikih
}

\author{
Arwin Juli Rakhmadi Butar-Butar \\ Dosen FAI UMSU dan Kepala Observatorium Ilmu Falak UMSU \\ (Email: arwin_buntupane@yahoo.co.uk)
}

\begin{abstract}
Abstrak
Ilmu Falak sebagai cabang ilmu pengetahuan tua senantiasa dikaji manusia sepanjang zaman. Di zaman silam ilmu ini dikenal dengan banyak penamaan seperti hay'ah, nujum, ahkam an-nujum, tanjim, dan lain-lain. Di era Islam ilmu ini berkembang dengan berbagai elaborasi dan akselerasi ilmiah hingga melahirkan temuan-temuan terkini nan teruji serta berguna dalam menentukan waktu-waktu ibadah. Puncak kecemerlangan Ilmu Falak dalam Islam mulai terjadi pada era Abbasiyyah, tepatnya pemerintahan Ja'far al Mansur. Kala itu, Ilmu Falak berada pada posisi istimewa, Ilmu Falak saat itu tidak hanya dipelajari dan dilihat dalam perspektif keperluan praktis ibadah saja, namun lebih dari itu, ilmu ini lebih dikembangkan sebagai pondasi dasar terhadap perkembangan sains modern seperti observasi benda-benda angkasa, pelayaran, pertanian, kemiliteran, pemetaan, dan lain-lain.

Dalam khazanah fikih Islam, nuansa Ilmu Falak tidak bisa lepas dalam pembahasan waktu-waktu shalat, arah kiblat dan penentuan puasa dan hari raya dengan segala perdebatannya. Penentuan waktu-waktu ibadah dengan bantuan Ilmu Falak di era modern tidak dipungkiri lagi fungsi dan manfaatnya. Banyak persoalan teknis ibadah yang tidak bisa diselesaikan dengan fikih an sich, melainkan dibutuhkan sumbangsih Ilmu Falak.
\end{abstract}

\section{A. Pendahuluan}

Ilmu Falak adalah Ilmu yang mempelajari tentang tata lintas pergerakan benda-benda angkasa, khususnya bumi, bulan dan matahari dalam garis edarnya masing-masing, untuk diambil fenomenanya dalam rangka kepentingan manusia, khsusus umat Islam ilmu ini berguna dalam menentukan waktu-waktu ibadah. Ibnu Khaldun (w. $808 \quad$ H) mendefinisikan ilmu ini sebagai ilmu yang membahas tentang pergerakan bintang-bintang (planet-planet) yang tetap, bergerak dan gumpalan- gumpalan awan yang berhamburan di angkasa. ${ }^{1}$

Secara bahasa 'falak' berarti orbit atau lintasan, dalam bahasa Yunani disebut astronomi (astro bermakna bintang dan nomos bermakna ilmu). Di Indonesia ilmu ini dikenal dengan Ilmu Falak, dan dalam kaitannya dengan waktu-waktu ibadah, ilmu ini disebut Ilmu Falak Syar'iy atau ilmu hisab dan rukyat. Penamaan Ilmu Falak sangat beragam dalam khazanah turats, antara lain:

\footnotetext{
1 Abdurrahman bin Khaldun, Muqaddimah Ibnu Khaldun, Editor: Hamid Ahmad at Thahir, Dar al Fajr li[t] Turats, cet. I, 1425 H/2004 M, h. 602
} 

Butar-Butar)

Ilmu Nujum, Ilmu Hay'ah, Ilmu Hay'atu[l] Aflak, Ilmu Aflak (Falak), Ilmu Shina'ah an-Nujum, Ilmu Tanjim, Ilmu Ahkam an-Nujum, dan lain-lain. $^{2}$

Khusus dalam Islam, pembahasan utama Ilmu Falak membahas materi-materi yang berkaitan dengan waktu-waktu ibadah, yaitu: penentuan awal bulan, penentuan waktu-waktu shalat, penentuan arah kiblat, dan penentuan terjadinya gerhana.

\section{B. Arah Kiblat}

Kiblat adalah bangunan berbentuk kubus terletak dijantung kota Mekah sebagai tempat yang dituju kaum muslimin dalam shalat. Menghadap kiblat adalah satu kemestian (syarat) untuk sahnya shalat. Ada banyak ayat dan hadis yang menyatakan wajibnya menghadap baitullah (ka'bah dalam shalat. Namun ulama berbeda pendapat tentang detail menghadap yang dimaksud. Sebagian ulama berpendapat yang diwajibkan adalah menghadap benda atau bangunan ('ain) Ka'bah, sebagian ulama lagi menyatakan arah (jihah, ishabah) Ka'bah saja.

Di era modern, ada beberapa cara yang dapat digunakan untuk menentukan arah kiblat, yaitu: [a.] Ilmu Ukur Segi tiga Bola

${ }^{2}$ Abdul Amir al Mukmin, At Turats al Falaky 'Inda al 'Arab wal Muslimin wa Atsaruhu fi 'Ilmi[l] Falak al Hadits, Terbitan Universitas Aleppo-Syria, 1413 H/ 1991 M, 18
Menentukan Ka'bah yang berada di kota Mekah dapat diketahui dari seluruh permukaan bumi dengan sistem ilmu ukur segi tiga bola (Spherical Trigonometri). Data-data yang dibutuhkan adalah:

1. Lokasi Ka'bah (Lintang \& Bujur), dimana Lintang $(\varphi)=$ $21^{\circ} 25^{\prime}$ dan Bujur $(\gamma)=39^{\circ}$ 50 ')

2. Data geografis lokasi setempat (lokasi yang akan dihitung arah kiblatnya).

Dalam menentukan arah kiblat, dapat dilakukan dengan menggunakan rumus berikut: $\mathrm{AQ}=$ ATN $(1 /(\operatorname{cotan} b x \sin a / \sin c-\cos a x$ $\operatorname{cotan} c))$ dimana $(a=90-P E, b=90-$ PK , $c=L E-L K)$. Misalnya arah kiblat kota Medan Sumatera Utara.

Dimana:

- Lokasi Ka'bah : Lintang $(\varphi)=$ $21^{\circ} 25^{\prime}$ dan Bujur $(\gamma)=39^{\circ}$ 50 ')

- Lokasi kota Medan : Lintang $(\varphi)=03^{\circ} 38^{\prime}$ dan Bujur $(\gamma)=$ $\left.99^{\circ} 38^{\prime}\right)$

Maka:

$\mathrm{a}=90-3^{\circ} 38^{\prime}=86,366666667\left(86^{\circ}\right.$

22')

$\mathrm{b}=90-21^{\circ} 25^{\prime}=68,58333333\left(68^{\circ}\right.$

35')

$\mathrm{c}=98^{\circ} 38^{\prime}-39^{\circ} 50^{\prime}=\left(58^{\circ} 48^{\prime}\right)$

Maka:

$\mathrm{AQ}=\mathrm{ATN}\left(1 /\left(\operatorname{cotan} 68^{\circ} 35^{\prime} \mathrm{x} \sin \right.\right.$ $86^{\circ} 22^{\prime} / \sin 58^{\circ} 48^{\prime}-\cos 86^{\circ} 22^{\prime} x$ $\left.\left.\operatorname{cotan} 58^{\circ} 48^{\prime}\right)\right)=67,25393198$ atau 
$67^{\circ} 15^{\prime} 14,16^{\prime \prime}$. Maka arah kiblat kota Medan adalah $67^{\circ} 15^{\prime}$ atau $292^{\circ} 45^{\prime}$.

[b.] Bayang-Bayang Kiblat

Selain dengan menggunakan perhitungan ilmu ukur segi tiga bola, penentuan arah kiblat juga bisa dilakukan dengan menggunakan fenomena bayang matahari (bayang kiblat), dengan rumus berikut: $\mathrm{BQ}=$ $\mathrm{MP}+\mathrm{KWK}+(\mathrm{SF}-\mathrm{SQ}) / 15$ dan [ $\mathrm{KWK}=(\mathrm{WK}-\mathrm{LE}) / 15] \quad[\mathrm{SF}=\mathrm{atn}$ $(1 /(\tan \mathrm{AQ} x \sin \mathrm{PE})]$ [ SQ $=\mathrm{ACS}$ ( $\cos \mathrm{SF} x \operatorname{cotan} \mathrm{PE} x \tan \mathrm{DS})]$.

Misalnya kita hendak menentukan bayang kiblat pada tanggal 14 Agustus 2008 di kota Cairo, Mesir $\left(\varphi 30^{\circ} 03^{\prime}, \gamma=31^{\circ} 15^{\prime}\right)$. Maka, $B Q=12,08100167+$ $0,083333333+(64,34961686$ $78,76670534) / 15=11,0365291$. Maka Bayang Kiblat di kota Kairo tanggal 14 Agustus $2008=$ 11,0365291 (jam 11:02 Waktu Cairo). ${ }^{3}$

[c.] Fenomena Rashdul Kiblat

Selain dua cara di atas (perhitungan arah kiblat dan bayang matahari), penentuan arah kiblat dapat dilakukan melalui momen alami matahari tanpa perlu melakukan perhitungan sedikitpun. Peristiwa ini disebut dengan Istiwa' A'zham atau Rashdul Qiblah, yaitu setiap:

\footnotetext{
${ }^{3}$ Pada hari dan jam tersebut, penulis dan rekan-rekan kajian Falak Pelangi \& AFDA PCIM Kairo telah melakukan praktek penentuan bayang kiblat tersebut di Suq Sayyaroh H-10 Kairo.
}

28 Mei 2008 jam

16:18 WIB (Hari ke-

1)

16 Juli 2008 jam

16:27 WIB (Hari ke-

2)

Maka pada saat tersebut, jika kita menarik garis lurus dari matahari, kita akan mendapatkan posisi tepat arah kiblat tanpa perlu melakukan perhitungan.

\section{Penentuan Kiblat Dalam Khazanah Fikih}

Terdapat ragam pendapat dikalangan ulama tentang penentuan arah kiblat, yaitu sebagai berikut:

- Hanafiyah:

1. Berpatokan pada masjidmasjid yang dibangun para Sahabat. $^{4}$

2. Bertanya kepada orang lain, dengan urutan; Bertanya pada yang terdekat (penduduk setempat), yang ditanya (al mas'ul) mengerti arah kiblat, yang ditanya legal (bukan kafir, fasiq dan anak-anak).

3. Jika dua cara diatas tidak ada, shalatlah dengan apa adanya (zhan).

- Malikiyah:

1. Berpatokan pada masjidmasjid Sahabat.

\footnotetext{
${ }^{4}$ Masjid-masjid Sahabat a.l.: Masjid
} Bani Umayyah di Damaskus-Syria, Masjid Amru bin Ash di Kairo-Mesir, Masjid Qairawan di Maroko, dll. 
2. Mencari/meneliti (taharra) jika mampu melakukannyatanpa boleh bertanya pada orang lain.

3. Bertanya pada orang lain dalam ketiada-mampuan dan ketiada-tersediaan alat untuk menentukan.

- Syafi'iyah:

1. Mencari/menetapkan sendiri tanpa bertanya pada orang lain.

2. Bertanya pada orang yang dapat dipercaya (tsiqah) lagi ahli dalam menentukan arah kiblat

3. Berijtihad

4. Mengikut orang berijtihad dalam menentukan arah kiblat (taqlid al mujtahid).

- Hanabilah:

1. Berpatokan pada masjidmasjid Sahabat.

2. Bertanya pada orang adil, jika orang yang memberi informasi (mukhbir) mengetahui secara pasti, wajiblah mengikutinya, dan jika hanya dugaan kuat (zhan) saja, bolehlah mengikutinya dengan syarat jika waktu shalat telah sempit, namun jika waktu shalat masih lapang diharuskan mencari tahu lebih dahulu.

\section{Waktu Shalat}

Shalat merupakan ibadah penting dalam Islam, dalam menunaikannya seorang muslim terikat pada waktu-waktu yang sudah ditentukan. Konsekuensi logisnya, shalat tidak bisa dilakukan di sembarang waktu, tetapi harus mengikuti petunjuk al Qur'an dan as Sunnah.

Waktu shalat dari hari ke hari dan antara satu tempat dengan tempat lainnya berbeda-beda sesuai dengan peredaran relatif matahari dan bumi. Dalam penentuan waktu shalat, data astronomi yang dibutuhkan adalah: ketinggian, jarak zenit, awal fajar, Matahari terbit, kulminasi, Matahari terbenam, akhir senja, data geografis (lintang dan bujur), tanggal dan lokasi. Ilmu Falak berperan menafsirkan fenomena yang disebutkan dalil al-Qur'an dan alHadits terkait dan teraplikasikan dalam bentuk rumus matematis. Dalam penetapan waktu-waktu shalat, secara umum masyarakat telah sepakat menerima data astronomi atau hisab sebagai acuan. ${ }^{5}$

Adapun data Astronmis Waktu-Waktu Shalat adalah sebagai berikut:

1. Zuhur : Sejak Matahari
meninggalkan
meridian
(gelincir Matahari) sampai
panjang bayangan sebuah
benda lebih panjang dari
obyek sebenarnya (MP +
KWK).

5 Lihat: Susiknan Azhari, Awal Waktu Shalat Perspektif Syar'i dan Sains (Artikel dimuat dalam majalah Suara Muhammadiyah, No. 2, Th. Ke-92, 16-31 Januari 2007) 
2. Ashar : [1] Ketika panjang bayang suatu benda sama dengan tinggi benda sebenarnya (MP + KWK + TS Asar + 1), [2] Ketika panjang suatu benda dua kali tinggi benda sebenarnya (MP + $\mathrm{KWK}+\mathrm{TS}$ Asar + 2).

3. Maghrib : Saat terbenamnya Matahari sampai hilangnya cahaya merah di langit barat (jarak zenith $\mathrm{z}=90^{\circ} 50^{\prime}$ (The Astronomical Almanac) atau $\mathrm{z}$ $\left.=91^{\circ}\right)(\mathrm{MP}+\mathrm{KWK}+\mathrm{TS}$ Magrib).

4. Isya' : Ditandai dengan mulai memudarnya cahaya merah di ufuk barat (akhir senja astronomi (astronomical twilight) yaitu bila jarak zenit matahari $\mathrm{z}=108^{\circ}$. Pada saat itu matahari berkedudukan 18 derajat di bawah ufuk (horizon) sebelah barat (MP + KWK + TS Isya').

5. Subuh : Sejak terbit fajar shadiq (fajar sebenar) hingga terbitnya Matahari (awal fajar astronomi (astronomical twilight), yaitu semenjak munculnya cahaya di ufuk timur menjelang terbit Matahari kira-kira $18^{\circ}$ di bawah horizon (jarak zenit $\mathrm{z}$ $\left.=110^{\circ}\right)(\mathrm{MP}+\mathrm{KWK}+\mathrm{TS}$ Subuh).

6. Syuruq : Saat terbitnya matahari yang menandakan berakhirnya waktu Shubuh (MP + KWK - Ts Magrib)
Misalnya perhitungan waktu shalat untuk kota Medan Sumatera Utara tanggal 25 Maret 2007. Dimana data Geografis kota Medan: Lintang $(\varphi)=03^{\circ} 38^{\prime} \mathrm{LU}$, Bujur $(\delta)=98^{\circ} 38^{\prime}$ BT, Bujur Waktu (Waktu Tolok) = 105

Rumus:

$$
\begin{gathered}
\mathrm{W}=\mathrm{MP}+\mathrm{KWK}+\mathrm{TS} \\
\mathrm{TS}=\mathrm{ACS}((\cos \mathrm{z}-\sin \mathrm{DS} \times \sin \mathrm{PE}) \\
/ \cos \mathrm{DS} \times \cos \mathrm{PE}) / 15 \\
\text { Zenit Ashar }(\mathrm{ZA})=\mathrm{ATN}(\tan / \mathrm{DS}- \\
\mathrm{PE} /+1) \\
\text { Zenit Magrib }(\mathrm{ZM})=90+\mathrm{RF}+\mathrm{SD}+ \\
\text { DP atau ZM }=91 \\
\text { Zenit Isya' }=108, \text { Zenit Shubuh }= \\
\text { 110, DS }: 1,543182648, \mathrm{KWK}: \\
0,424444444, \mathrm{MP}: 12,10402574
\end{gathered}
$$

Maka: $\mathrm{W}=\mathrm{MP}+\mathrm{KWK}+\mathrm{TS}$

$\mathrm{TS}=\mathrm{ACS}((\cos \mathrm{z}-\sin \mathrm{DS} \mathrm{x} \sin \mathrm{PE})$ / $\cos \mathrm{DS} x \cos \mathrm{PE}) / 15$

TS Zuhur $\quad$ MP + KWK $\rightarrow$ $12,52847018 \rightarrow(12: 31 \mathrm{WIB})$

TS Asar : 2,944888298 $\rightarrow$ waktu Asar $=15,47335848 \quad(15: 28$ WIB)

TS Magrib $\quad$ : 6,073065904 $\rightarrow$ waktu Magrib = 18,60153609 (18:36) TS Isya' $\quad:$ 7,20479873 $\rightarrow$ waktu Isya' $=19,73326891=(19: 43 \mathrm{WIB})$

TS Subuh $\quad$ : 7,337969059 $\rightarrow$ waktu Shubuh $=5,190501125(5: 11$ WIB)

TS Syuruq : MP + KWK - TS Magrib $\rightarrow$ waktu Syuruq = 6,275404276 (6:16 WIB) 


\section{E. Waktu Shalat Dalam} Khazanah Fikih

Waktu-waktu

shalat

sesungguhnya merupakan hasil

ijtihad para ulama ketika menafsirkan ayat-ayat al Qur'an dan al Hadits terkait. Landasan dalam menetapkan awal dan akhir waktu shalatpun bersifat interpretatif, sebagai implikasinya muncul perbedaan dalam menetapkan awal dan akhirnya, yang tegas hanyalah bahwa shalat itu ketetapan yang sudah ditentukan (kitaban mawquta).

\section{Waktu Zhuhur}

Dalam penetapan waktu zhuhur ulama sepakat awal waktu zhuhur bermula ketika matahari tergelincir s.d. menjelang waktu Ashar (sampai panjang suatu benda lebih panjang dari obyek bendanya). Namun tentang akhir waktu Zhuhur, Malikiyah menyatakan: diantara akhir waktu zhuhur dan awal waktu Ashar terdapat waktu transisi yaitu sekitar seukuran shalat empat raka'at. ${ }^{6}$

\section{Waktu Ashar}

Menurut jumhur, waktu Ashar bermula ketika panjang suatu benda sama dengan tinggi benda sebenarnya (hyna shara zhill[u] kull[i] syai'in

6 Ibnu Rusyd, Bidayatul Mujtahid wa Nihayah al Muqtasid, j. I, Editor: Ahmad Abu al Majd, Darul Aqidah-Kairo, cet. I, 1425 H/2004 M, h. 121. Muhammad bin Ali as Syaukani, op.cit., h. 347. Baha'uddin Abdurrahman al Maqdisi, Al 'Uddah Syarh al 'Umdah fi Fiqh Imami[s] Sunnah Ahmad bin Hanbal, Editor: Ahmad bin Ali, Daru[1] Hadits-Kairo, 1424 H/2003, h. 65-66 mitslah $[u])$. Namun menurut Hanafiyah, waktu Ashar bermula ketika panjang suatu benda dua kali dari panjang sebenarnya (hyna shara zhill[u] kull[i] syai'in mitslayh[i]). ${ }^{7}$ Perbedaan ini disebabkan adanya dua redaksi hadits Nabi Saw. dimana satu ketika Nabis Saw. diajak shalat Ashar oleh Jibril as. ketika panjang suatu benda satu kali panjang benda sebenarnya, dikali yang kedua Nabi Saw. diajak shalat Ashar oleh Jibril as. ketika panjang suatu benda dua kali dari panjang sebenarnya (HR. Nasa'i, Ahmad dan Turmudzi). ${ }^{8}$

Tentang akhir waktu Ashar, menurut Malikiyah terdapat dua pendapat: [1.] Ketika panjang suatu benda dua kali dari panjang sebenarnya, pendapat ini juga didukung oleh sebagian Syafi'iyah [2.] Selama matahari belum menguning, pendapat ini didukung juga oleh Hanabilah. ${ }^{9}$ Sementara itu Zhahiriyah memandang akhir Ashar sebelum terbenam matahari seukuran

\footnotetext{
${ }^{7}$ Lihat: Ibnu Rusyd, op.cit., h. 119

${ }^{8}$ Muhammad bin Ali as Syaukani, loc.cit.

9 Hal ini disebabkan adanya tiga redaksi hadits yang secara zhahir terlihat bertentangan, yaitu: [1.] Riwayat Abdullah bin Umar: فإذا صليتم العصر فإنه وقت إلى أن تصفر ]

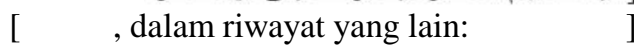
[

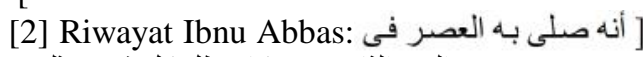
اليوم الثاني حين كان ظل كل شيئ مثليه]

[3.] Riwayat Abu Hurayrah:

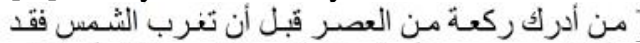

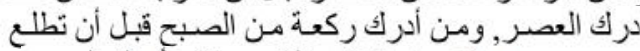

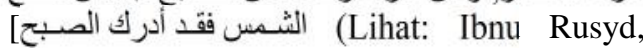
op.cit., h 122)
} 
shalat satu raka'at, pendapat ini juga dianut oleh jumhur. ${ }^{10}$

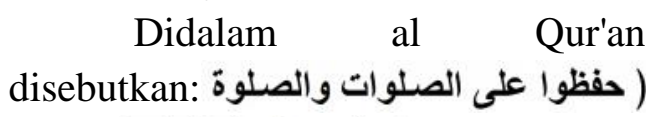
Oleh sebagian ulama ayat ini ditafsirkan sebagai shalat Ashar yang merupakan waktu pertengahan antara Zhuhur dan Maghrib. ${ }^{11}$ Jika pendapat ini digunakan, waktu Ashar akan lebih cepat dari jadwal shalat yang digunakan selama ini.

\section{Waktu Magrib}

Waktu Magrib bermula sejak terbenam Matahari sampai hilangnya cahaya merah di langit barat (antara terbenam matahari hingga terbenamnya syafaq). ${ }^{12}$

\section{Waktu Isya'}

Malikiyah dan Syafi'iyah menyatakan waktu Isya' bermula sejak hilangnya mega merah, sementara Hanafiyah menyatakan semenjak hilangnya mega putih setelah mega merah. ${ }^{13}$ Perbedaan ini disebabkan perbedan pemaknaan terhadap kata mega awan (syafaq) dalam pemahaman kaum Arab. Dimaklumi mega (syafaq) terbagi

10 Ibid. Muhammad bin Ali as Syaukani, op.cit., h 351

11 Terdapat beragam penafsiran dikalangan ulama tafsir terhadap ayat diatas. Diantaranya ada yang menyebutkan 'shalat pertengahan' itu sebagai shalat Shubuh, ada pula yang menafsirkan zhuhur, ada juga yang mengatakan shubuh dan Ashar, dll.

${ }^{12}$ Baha'uddin Abdurrahman at Maqdisi, op.cit., h. 66

${ }^{13}$ Ibnu Rusyd, op.cit., h. 123 dua: mega merah (syafaq ahmar) dan mega putih (syafaq abyadh), sebagaimana fajar juga terbagi dua: fajar sebenar (fajr shadiq) dan fajar dusta (fajr kadzib). Jumhur memaknai awal Isya' dengan syafaq ahmar hingga terbit fajar, karena zhahir hadits-hadits waktu shalat menyatakan waktu-waktu shalat terus besambung dari satu shalat dengan shalat berikutnya, kecuali shalat Shubuh yang berakhir ketika terbit matahari. ${ }^{14}$

Namun ulama berbeda pendapat lagi tentang akhir waktu Isya' dalam tiga pendapat: [1] Berakhir disepertiga malam (Syafi'iyah, Hanafiyah dan sebagian Malikiyah) [2] Berakhir dipertengahan malam (sebagian Malikiyah) [3] Berakhir hingga terbit fajar (Dawud). Penyebab perbedaan tersebut bersumber dari beberapa redaksi hadits yang berbeda. Hadits Jibril as. menyatakan, Nabi Saw. mengakhirkan shalat Isya' hingga sepertiga malam. Sementara hadits Anas ra. menyatakan, Nabi Saw. menegaskan keutamaan mengakhirkan shalat Isya' dipertengahan malam. ${ }^{15}$

${ }^{14}$ Sayyid Sabiq, Fiqh as Sunnah, j. I, Dar al Fath-Kairo, cet. II, 1419 H/1999 M, h. 124

[ أخر النبي صلى الله عليه وسلم صـلاة: 15 العشاء إلى نصف على الليل ] (خرجه البخارى) Abu Hurairah dan Al Khudry : [ لو لا أن أنشق على أمني لأخرت العشاء إلى نصف الليل ] (Lihat: Ibnu Rusyd, op.cit. h. 124) 


\section{Waktu Shubuh}

Ulama sepakat, awal waktu

shubuh ketika terbit fajar dan

berakhir ketika terbit matahari. ${ }^{16}$

Hadits Nabi Saw. menyatakan: ]

$$
\text { [ } \quad \text { : } \quad \text { (متفق عليه) }
$$

\section{F. Awal Bulan Kamariah}

Penanggalan dalam Islam ditetapkan dengan sistem bulan (qamary) yaitu dengan terlihatnya hilal diakhir bulan atau dengan perhitungan. Satu bulan Qamariyah adalah jangka waktu yang dihabiskan bulan dalam fase-fasenya hingga sempurna, yaitu selama 29 hari 12 jam 44 menit 2,9 detik. Fase-fase tersebut adalah sbb.: [1.] Fase Crescent (hilal), yaitu manzilah pertama bulan dalam peredarannya mengelilingi bumi yang jika memungkinkan akan terlihat diufuk barat setelah matahari terbenam. Fase ini berakhir hinggga 6 hari 16 jam 11 menit. [2.] Fase First Quarter (tarbi' awwal), adalah bulan yang telah memasuki $1 / 4$ peredarannya, yaitu mulai dari hari ke 7. [3.] Fase First Gibbous (ahdab awwal), yaitu bulan yang sudah mulai mendekati ufuk timur, dengan bentuknya yang sudah semakin membesar, yaitu telah sampai hari ke 11 dengan lengkung sabit menghadap timur. [4.] Fase Full Moon (badar), yaitu bulan yang telah

\footnotetext{
${ }^{16}$ Ibid, h. 125

17 Ibnu Qudamah, Al Mughny,
} Editor: Dr.Abdullah Muhsin at Turki \& Dr.Abdul Fattah al Halw, j. II, Dar 'Alam al Kutub-Riyadh, cet. V, 1426 H/2005 M, h. 30 mencapai usia pertengahan dimana posisinya tepat berhadapan dengan matahari, dan bentuknya telah bulat sempurna. [5.] Fase Second Gibbous (ahdab tsany), yaitu masa setelah berlalunya fase full moon yang hampir seukuran dengan ahdab awwal (first gibbous) namun dengan arah lengkung sabit yang berlawanan (menghadap barat). [6.] Fase Second Quarter (tarbi' tsany), yaitu fase bulan yang telah berlalau sekitar 22 1/8 hari yang mirip tarbi' awwal (first quarter) dengan arah lengkung sabit yang berkebalikan (menghadap barat), yang terus bergerak sedikit demi sedikit menuju arah ufuk barat. [7.] Fase Second Crescent (hilal tsany), yaitu masa setelah berlalunya tarbi' tsany (second quarter), dimana cahayanya menutupi sebagian kecil bagian kanan yang berbentuk seperti hilal. [8.] Fase Wane (mahaq), yaitu masa sampainya bulan pada peredaran sempurna, dimana bumi dan matahari dalam posisi sejajar, yang disebut dengan konjungsi (iqtiran) atau ijtimak, dan nyaris tidak terlihat dari bumi dikarenakan gelap. ${ }^{18}$

Konjungsi atau ijtimak merupakan syarat awal masuknya bulan baru Qamariyah secara astronomis, yaitu saat bulan berada diantara matahari dan bumi (fase wane/al mahaq), dimana wajah bulan

18 Prof.Dr.Muhammad Ahmad Sulaiman, Sibahah Fadha'iyyah fi Afaq 'Ilm[il] Falak, Maktabah al 'Ujairy-Kuwait, 1420 H/1999 M, h. 51 s.d. 52 
menjadi tidak nampak dari bumi. Secara detil, ijtimak atau konjungsi merupakan pertemuan atau berimpitnya dua benda yang berjalan secara aktif yang terletak pada posisi garis bujur yang sama bila dilihat dari arah timur ataupun arah barat. Namun karena tipisnya, hilal sangat sulit dapat dilihat dari bumi, karena bulan yang sedang berijtimak berdekatan letaknya dengan matahari. ${ }^{19}$

\section{G. Karakteristik Bulan Kamariyah \\ Terdapat beberapa \\ karakteristik hilal yang perlu dipahami terkait dengan penentuan hilal awal bulan, yaitu sbb.:}

1. Bulan terbenam lebih dahulu dari matahari (hilal masih/sudah berada dibawah ufuk, alias hilal negatif). Dalam keadaan ini, hilal dipastikan tidak terlihat, dan setiap kesaksian akan tertolak.

2. Matahari terbenam lebih dulu dari bulan. Dalam keadaan ini, ada kemungkinan hilal terlihat, namun bergantung ketinggiannya diatas ufuk.

3. Hilal terlihat setelah terbenamnya matahari sebelum terjadi konjungsi. Hal ini belum terhitung sebagai hilal awal bulan dan masih terhitung sebagai hilal akhir bulan. (fenomena ini

19 Susiknan Azhari, Ensiklopedi Hisab Rukyat, Penerbit: Pustaka Pelajar Yogyakarta, 2005 terhitung ganjil dan jarang terjadi).

4. Terjadinya konjungsi ketika terbenamnya Matahari dalam keadaan tertutup (kasyifah) alias terjadi gerhana matahari, maka dipastikan hilal tidak akan terlihat karena kekontrasan cahaya Matahari.

5. Bulan terbenam setelah terbenamnya Matahari, sementara itu diwilayah lain sebaliknya (dalam satu wilayah kesatuan/negara). Maka dalam hal ini, setiap wilayah berlaku penetapan masing-masing berlandaskan pada hadits Kuraib. ${ }^{20}$

\section{H. Kesaksian (Syahadah) Dalam Rukyat}

Terdapat keragaman

dikalangan fuqaha' dalam menetapkan kesaksian dalam rukyat. Hanafiyah menetapkan jika awan dalam keadaan cerah, maka dengan rukyat kolektif (ru'yah jama'ah) dan tidak dapat diperpegangi kesaksian orang per-orang menurut pendapat yang rajih, dengan alasan; dalam keadaan cuaca cerah tentu tidak ada penghalang bagi seseorang untuk tidak dapat melihat hilal sementara

20 Terkadang point 4 dan 5 dikembalikan kepada penguasa sebagai ulil amri. (Lihat: Prof.Dr.Muhammad Ahmad Sulaiman, Nahwu Shiyaghah Mabady' at Taqwim al Islamy al 'Alamy, Makalah Seminar Internasional Tentang Kalender Islam di Jakarta Indonesia tahun 2007 M, h. 18). 
yang lain melihat. Namun jika hilal dalam keadaan tidak memungkinkan untuk dilihat karena mendung dll., mencukupilah kesaksian satu orang dengan syarat ia beragama Islam, adil, berakal dan dewasa. ${ }^{21}$

Sementara Syafi'iyah dan Hanabilah menetapkan minimal dengan kesaksian (rukyat) satu orang baik cuaca dalam keadaan cerah atau mendung, dengan catatan; perukyat beragama Islam, dewasa, berakal, merdeka, laki-laki dan adil. Selanjutnya kesaksian (rukyat) tersebut dipersaksikan dihadapan qadhi (pemerintah) bedasarkan hadits dari Ibnu Umar r.a. ${ }^{22}$ Selanjutnya wajib pula terhadap orang yang melihat hilal untuk berpuasa meskipun tidak dipersaksikan dihadapan qadhi (pemerintah), begitu pula terhadap orang yang percaya dan meyakininya ( liman shaddaqahu) meskipun orang yang melihat hilal tersebut anak-anak (shabiy), wanita, hamba, orang fasik bahkan orang kafir sekalipun. $^{23}$ Hal ini adalah dalam rangka kehati-hatian dalam masuknya waktu ibadah (Ramadhan), sebab puasa pada Sya'ban lebih ringan dari berbuka di bulan Ramadhan.

21 Abdurrahman al Jaziri, Kitab al Fiqh 'ala al Madzahib al Arba'ah, j.I, Mu'assasah al-Mukhtar-Kairo, cet.I, $2001 \mathrm{M}$, h. 421

${ }^{22}$ Muhammad Ibn Ali as-Syaukani, j.IV, op.cit., h.597. Redaksi hadits sbb.:

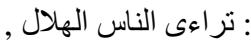

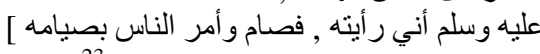

${ }^{23}$ Abdurrahman al-Jaziri, Loc.cit
Adapun Malikiyah menetapkan dengan tiga kriteria: [1.] Rukyat kolektif [2.] Rukyat satu orang adil [3.] Rukyat dua orang adil. Point (1) dan (2) dengan dalil terdahulu.

Seiring majunya zaman dan peradaban, tekstualis hadits dan pendapat-pendapat para ulama terdahulu mulai bergeser dan disinergikan dengan kondisi kekinian. Prof.Dr.Muhammad Ahmad Sulaiman (Guru besar astronomi Ma'had al Qawmy lil Buhuts al Falakiyyah wal Geofiziqiyyah Helwan - Mesir) menyebutkan, terdapat beberapa kriteria yang harus terpenuhi demi sahnya kesaksian rukyat secara syar'iy dan 'ilmy, yaitu: sehat jasmani dan rohani (akal), jelas penglihatan, adil dan terpercaya, dan memahami teks dan konteks rukyat. ${ }^{24}$

Terhadap point 1,2, dan 3, agaknya banyak orang yang mampu melakukannya, karena kelengkapan ini pada umumya dimiliki manusia. Namun khusus point 4, diperlukan kedetilannya, meliputi: [1.] Pemahaman lapangan; area rukyat ter-ideal adalah pinggir laut lepas dan bebas tanpa penghalang atau tempat yang tinggi. [2.] Waktu rukyat; yaitu semenjak terbenamnya matahari setelah terjadinya konjungsi. [3.] Memahami keadaan teknis hilal; hilal tanggal satu adalah hilal yang tanduknya mengarah ke timur, jika sedikit mengarah ke bawah (barat)

24 Prof.Dr.Muhammad Ahmad Sulaiman, op.cit., h. 19 
masih terhitung hilal akhir bulan, munculnya hilal disebelah barat, area munculnya hilal sejaun 8 derajat kesebelah kanan dan kiri matahari terbenam dan 15 derajat sebelah atas terbenamnya matahari.

Ringkasnya; apa, bagaimana, berapa lama, kapan dan dimana hilal itu ? Deretan pertanyaan teknis hilal ini perlu dipahami secara baik oleh para perukyat, sebab kenyataan dilapangan, banyak perukyat yang tidak memahami hal-hal teknis ini, yang terjadi hanya tunduk patuh terhadap literalis hadits tanpa riset dan reserv ilmiah. Hadits Nabi Saw. memang sederhana, namun menuntut praktek tepat yang terkait dengan tiga fenomena alami benda angkasa (Bulan, Bumi dan Matahari). Rasul Saw. memang tidak pernah menanyakan serinci dan se-eksplisit ini, karena ketika itu sarana satusatunya hanyalah pengamatan, dan sahabatpun lihai dan piawai dengan fenomena langit.

\section{Perdebatan Antara Hisab dan Rukyat}

Perdebatan antara hisab \& rukyat telah lama terjadi, mulai ulama klasik sampai ulama dan ilmuan modern. Akar persoalan sesungguhnya terjadi pada perbedaan pandangan terhadap teks (al Qur'ah dan as Sunnah). Zhahir hadits-hadits Nabi Saw. tentang rukyat menjadi alasan utama jumhur dalam menetapkan awal puasa dan hari raya hanya dengan pengamatan empirik (rukyat).

Sementara itu, tidak dapat dipungkiri perkembangan dan kemajuan ilmu pengetahuan membawa konsekuensi kepada bergesernya ketetapan-ketetapan teks nash yang memungkinkan untuk dielaborasi dalam konteks modern. Pada dasarnya Islam adalah agama yang menghargai ilmu pengetahuan, dimana antara dimensi ideal wahyu dan peradaban manusia akan selalu berselaras. Tidak sedikit ulama \& ilmuan yang mentolerir penggunaan sains, termasuk didalamnya hisab, dalam menetapkan masuknya awal bulan qamariyah.

Imam Taqiyuddin as-Subki (w. $756 \mathrm{H}$ ) dalam Al-Fatawa-nya menyatakan kebolehan menggunakan hasil hisab sebagai penentu masuknya awal bulan. Menurut beliau, bila pada suatu kasus ada orang yang menyatakan (menyaksikan) bahwa hilal telah terlihat, sementara hisab akurat menunjukkan bahwa hilal tidak mungkin terlihat, maka informasi tersebut dianggap keliru dan kesaksian tersebut harus ditolak. Hal ini beliau kemukakan mengingat nilai khabar dan kesaksian bersifat zhan sedang hisab bersifat qath'I, telah dimaklumi bahwa sesuatu yang qath'I tidak dapat didahului atau dipertentangkan dengan sesuatu yang zhan. $^{25}$

${ }^{25}$ Taqiyuddin Ali as Subki, Fatawa as Subky, Maktabah al-Quds, j. I, t.t., h.217 $\&$ seterusnya. 
Pernyataan as-Subki ini selanjutnya mendapat dukungan dari beberapa ulama yang datang kemudian seperti imam As-Syarwani, Al-'Abbadi dan Al-Qalyubi (w.1069). Al-Qalyubi) menyatakan; "Yang benar, rukyat hanya sah pada waktu hilal memang mungkin terlihat". Secara lebih tegas As-Syarwani dan Al-'Abbadi mengatakan ;"Seyogianya, jika menurut hisab qath'I hilal telah berada pada posisi memungkinkan terlihat (haitsu tata'atta ru'yatuh) setelah matahari terbenam, kiranya hal itu telah cukup dijadikan acuan meskipun dalam kenyataan (zhahir) hilal tidak tampak". ${ }^{26}$

Terkait penggalan hadits Nabi Saw. "faqduru lah", jumhur ulama menerjemahkan: "Takdirkanlah dengan menggenapkan bilangan menjadi 30 hari”. Akan tetapi terdapat beberapa ulama yang menafsirkan lain terhadap hadits tersebut, a.l.: Ahmad bin Hanbal (w. $241 \mathrm{H}$ ) dan beberapa ulama lainnya menyatakan perintah itu bermakna; "anggaplah hilal itu ada dibalik awan" (wa qaddarahu tahta as sahab). Dengan demikian bila cuaca mendung pada saat terbenam matahari (ghurub) tanggal 29 Sya'ban, mereka tetap mewajibkan puasa esok harinya. Sementara

26 Abdul Hamid as-Syarwani, Hasyiyah as Syarwani, j.III, t.t., h. 382 dan seterusnya. Lihat juga: Syihabuddin alQalyubi, Hasyiyatani al Qalyubi wa 'Umairah, Mathba'ah Karya InsanIndonesia, j.II, t.t., h.49 dan seterusnya. menurut Mutharrif bin Abdullah (w. $87 \mathrm{H}$ ), seorang tabi'in besar, Ibnu Qutaibah (w. 276 H), Ibnu Suraij (w. $306 \mathrm{H})$, dll. menafsirkan: "Perkirakanlah dengan perhitungan al-manazil (perhitungan gerak bulan dan matahari). ${ }^{27}$. Sementara itu Ibnu Qudamah dalam "Al-Mughni"-nya menafsirkan kata "faqdurulah" tersebut dengan: "dhayyiqu lah[u] al 'adad" (ambil-lah bilangan tersingkat, yaitu menjadikan 29 hari). ${ }^{28}$

Diantara ulama kontemporer yang mengapresiasi penggunaan hisab dalam menentukan puasa dan hari raya a.l.: Thanthawi Jawhari dalam tafsirnya "Al-Jawahir fi Tafsir al-Qur'an al-'Azhim". Secara panjang lebar menyatakan kemestian menggunakan data hisab-falak dalam memulai puasa dan hari raya, hal ini dapat disimak dalam pandangan beliau ketika mengomentari QS.Yunus: 5 serta ayat-ayat yang berkaitan. $^{29}$

Selanjutnya ulama kharismatik Mesir Rasyid Ridha dalam tafsirnya "Al-Manar" juga menyerukan (membolehkan) untuk menggunakan data hisab-falak, antara lain dalam komentarnya terhadap

${ }^{27}$ Lihat: Yusuf al-Qaradhawi, Fiqh as Shiyam, Maktabah Wahbah-Kairo, cet.I, 1424 H-2003 M, h.26

${ }^{28}$ Ibnu Qudamah, op.cit., h. 332

${ }^{29}$ Lihat komentar luas beliau khusus QS. Yunus ayat 5, dalam : Thanthawi Jawhari, Al Jawahir fi Tafsir al Qur'an al 'Azhim, j.V, Dar Ihya' at-Turats al-'ArabiBeirut Libanon, cet.IV, 1412 H-1991 M, h.342 
ayat-ayat puasa dan perhitungan gerak bulan dan matahari. ${ }^{30}$

Selanjutnya lagi Ahmad Muhammad Syakir, juga menyatakan demikian dalam salah satu karyanya "Awa'il as-Syuhur al-'Arabiyah", bahkan ia mengatakan cukup banyak ahli fikih dan ahli hadits yang tidak mengetahui ilmu falak, kebanyakan mereka tidak mempercayai para pakar ilmu ini, terlebih-lebih mereka menganggap itu adalah sesuatu yang bid'ah. Sementara sebagian mereka yang percaya dan mengertipun, tidak pula mampu meng-elaborasi ilmu ini dengan tuntutan fikih. ${ }^{31}$ Dalam karyanya tersebut, Ahmad Muhammad Syakir mendedahkan kronologis pembolehan/pewajiban hisab-falak tersebut. Kesimpulannya, telah dimaklumi bahwa pada awalnya bangsa Arab sebelum dan diawal berkembangnya Islam tidak mengerti ilmu falak dengan pemahaman secara komprehensif (ma'rifatan 'ilmiyyatan jazimatan) sebab mereka adalah ummat yang ummi, tidak menulis dan menghitung. Karena itu Nabi Saw. menjadikan sarana termudah dalam menentukan awal Ramadhan-Syawal yang dapat dilakukan oleh semua

${ }^{30}$ Lihat: Rasyid Ridha, Tafsir alManar, Dar al-Fikr-Beirut, j.XI, cet.II, t.t., h.303. Data (pendapat) Rasyid Ridha ini juga dikutip Dr.Yusuf al Qaradhawi dalam mendukung pendapatnya dalam Fiqh asShiyam-nya. Awa'il syuhur al 'arabiyah, hal yajuzu syar'an itsbatuha bi al-hisab al-falaki, Maktabah Ibnu Taimiyah-Kairo, cet.II, 1407 H, h.8-9 bangsa Arab ketika itu, yaitu rukyat hilal dengan mata-kepala. Ini adalah sarana terbaik dan efektif dalam aktifitas ibadah mereka untuk menghasilkan rasa yakin dan percaya dalam batas kesanggupan mereka, karena sesungguhnya Allah Swt. tidak membebani hamba-Nya lebih dari kesanggupannya. Akan tetapi seiring tumbuh dan berkembangnya Islam dengan terjadinya berbagai kemenangan, diiringi pula dengan kemajuan yang pesat ilmu pengetahuan disemua disiplin, tanpa terkecuali ilmu hisab-falak (astronomi). Lantas beliau (baca: Ahmad Muhammad Syakir) memberi argumen dengan argumen seperti yang dikemukakan As-Subki dalam Al-Fatawa-nya. ${ }^{32}$

Dr.Yusuf al-Qaradhawi dalam "Fiqh[us] Shiyam"-nya menyebutkan pula secara tegas sekaligus menyeru untuk menerima fakta ini dengan mengutip pendapat Rasyid Ridha dan Ahmad Muhammad Syakir diatas. ${ }^{33}$ Demikian lagi Dr.Ali Jum'ah, Mufti Mesir, dalam fatwa kemasyarakatannya "Al Bayan Lima Yusyghil al Adzhan" menyatakan hal yang sama tentang kebolehan penggunaan ilmu hisab dalam menentukan masuknya Ramadhan dan Syawal.

\section{J. Kesimpulan}

1. Ilmu Falak merupakan Ilmu yang mempelajari tata

\footnotetext{
${ }^{32}$ Ibid, h.7-9

${ }^{33}$ Yusuf al-Qaradhawi, Op.cit, h.28
} 
pergerakan benda-benda angkasa, khususnya bumi, bulan dan matahari dalam garis edarnya masing-masing dalam rangka kepentingan manusia. Banyak persoalan dalam fikih Islam solusinya dapat dicari dalam Ilmu Falak seperti menentukan arah kiblat, menentukan waktu shalat, menentukan awal puasa dan hari raya, dan lainlain.

2. Kiblat sebagai arah yang dituju kaum muslimin didalam shalat merupakan satu keharusan (syarat) untuk sah dan berkualitasnya shalat yang dilakukan.

3. Dalam penentuan waktuwaktu shalat, teks-teks yang dijadikan landasan bersifat interpretatif. Sebagai implikasinya muncul perbedaan dan perdebatan dikalangan ulama dan ilmuan dalam menetapkan awal dan akhir waktu-waktu shalat tersebut.

4. Penentuan awal puasa dan hari raya merupakan persolan ijtihadiyah, perbedaan dan perdebatan merupakan keniscayaan, namun persatuan puasa dan hari raya dalam satu skup negara adalah satu keharusan.[]

\section{Daftar Pustaka}

- Abdurrahman bin Khaldun, Muqaddimah Ibnu Khaldun, Editor: Hamid Ahmad at Thahir, Dar al Fajr li at turats, cet. I, 1425 H/2004 M

- Abdul Amir al Mukmin, At Turats al Falaky 'Inda al 'Arab wal Muslimin wa Atsaruhu fi 'Ilmi[l] Falak al Hadits, Terbitan Universitas Aleppo-Syria, 1413 H/ 1991 $\mathrm{M}$

- Ahmad Muhammad Syakir, Awa'il syuhur al 'arabiyah, hal yajuzu syar'an itsbatuha bi al-hisab al-falaki, Maktabah Ibn TaimiyahKairo, cet.II, 1407 H

- Abdurrahman al Jaziri, Kitab al Fiqh 'ala al Madzahib al Arba'ah, j.I, Mu'assasah alMukhtar-Kairo, cet. I, $2001 \mathrm{M}$

- Baha'uddin Abdurrahman al Maqdisi, Al 'Uddah Syarh al 'Umdah fi Fiqh Imami[s] Sunnah Ahmad bin Hanbal, Editor: Ahmad bin Ali, Dar al Hadits-Kairo, 1424 H/2003

- Ibnu Rusyd, Bidayatul Mujtahid wa Nihayah al Muqtasid, j. I, Editor: Ahmad Abu al Majd, Darul AqidahKairo, cet. I, 1425 H/2004 M

- Ibnu Qudamah, Al Mughny, Editor: Dr.Abdullah Muhsin at Turki \& Dr.Abdul Fattah al Halw, j. II, Dar 'Alam al 
Kutub-Riyadh, cet. V, 1426 $\mathrm{H} / 2005 \mathrm{M}$

- Muhammad bin Ali as Syaukani, Naylul Awthar, Editor: Dr.Muhammad Muhammad Tamir, j. I, Dar Ibnul Haitsam-Kairo, tt.

- Muhammad Ahmad Sulaiman, Nahwu Shiyaghah Mabady' at Taqwim al Islamy al 'Alamy, Makalah Seminar Internasional Tentang Kalender Islam di Jakarta Indonesia tahun $2007 \mathrm{M}$

- Muhammad Ahmad Sulaiman, Sibahah Fadha'iyyah fi Afaq 'Ilm[il] Falak, Maktabah al 'UjairyKuwait, 1420 H/1999 M

- Rasyid Ridha, Tafsir alManar, Dar al-Fikr-Beirut, j.XI, cet.II, t.t.

- Susiknan Azhari, Awal Waktu Shalat Perspektif Syar'i dan Sains (Artikel dimuat dalam majalah Suara Muhammadiyah, No. 2, Th. Ke-92, 16-31 Januari 2007).

- Sayyid Sabiq, Fiqh as Sunnah, j. I, Dar al FathKairo, cet. II, 1419 H/1999 M

- Susiknan Azhari, Ensiklopedi Hisab Rukyat, Penerbit: Pustaka Pelajar Yogyakarta, 2005

- Syihabuddin al-Qalyubi, Hasyiyatani al Qalyubi wa 'Umairah, Mathba'ah Karya Insan-Indonesia, j.II, t.t.
- Taqiyuddin Ali as Subki, Fatawa as Subky, Maktabah al-Qudsi, j.I, t.t.

- TM.Ali Muda, Rumus Falak Sistem Jean Meeus (Diktat rumus mata kuliah Ilmu Falak I \& II Universita Islam Sumatera Utara), tt.

- Thanthawi Jawhari, Al Jawahir fi Tafsir al Qur'an al 'Azhim, j.V, Dar Ihya' atTurats al-'Arabi-Beirut Libanon, cet.IV, 1412 H-1991 $\mathrm{M}$

- Yusuf al-Qaradhawi, Fiqh as Shiyam, Maktabah WahbahKairo, cet.I, 1424 H-2003 M 